Check for updates

Cite this: Phys. Chem. Chem. Phys., 2020, 22, 4516

Received 5th October 2019 Accepted 18th December 2019

DOI: $10.1039 / c 9 c p 05454 e$

rsc.li/pccp

\section{Attack of hydroxyl radicals to $\alpha$-methyl-styrene sulfonate polymers and cerium-mediated repair via radical cations $\dagger$}

\begin{abstract}
Tom M. Nolte, (D) $\ddagger^{\mathrm{ab}}$ Thomas Nauser (D) $^{\mathrm{b}}$ and Lorenz Gubler (D) $^{\mathrm{a}}$
Both synthetic polymers (membranes, coatings, packaging) and natural polymers (DNA, proteins) are subject to radical-initiated degradation. In order to mitigate the deterioration of the polymer properties, antioxidant strategies need to be devised. We studied the reactions of poly ( $\alpha$-methylstyrene sulfonate), a model compound for fuel cell membrane materials, with different degrees of polymerization with $\mathrm{OH}^{\bullet}$ radicals as well as subsequent reactions. We observed the resulting $\mathrm{OH}^{\bullet}$-adducts to react with oxygen and eliminate $\mathrm{H}_{2} \mathrm{O}$, the relative likelihood of which is determined by $\mathrm{pH}$ and molecular weight. The resulting radical cations can be reduced back to the parent molecule by cerium(III). This 'repair' reaction is also dependent on molecular weight likely because of intramolecular stabilization. The results from this study provide a starting point for the development of new hydrocarbon-based ionomer materials for fuel cells that are more resistant to radical induced degradation through the detoxification of intermediates via damage transfer and repair pathways. Furthermore, a more fundamental understanding of the mechanisms behind conventional antioxidants in medicine, such as ceria nanoparticles, is achieved.
\end{abstract}

\section{Introduction}

Oxidative stress is a critical lifetime-limiting factor for sulfonated polyaromatic proton exchange membranes (PEMs) in the polymer electrolyte fuel cell (PEFC). These ionomers are of interest to replace the widely used perfluoroalkylsulfonic acid (PFSA) membranes, owing to their much lower gas permeability, higher glass transition temperature, and potentially lower cost. ${ }^{1}$ Oxidative stress is created by the presence of radical species, such as $\mathrm{HO}^{\bullet}, \mathrm{H}^{\bullet}$ and $\mathrm{HOO}^{\bullet}$, which are formed during the operation of the fuel cell in the presence of $\mathrm{H}_{2}, \mathrm{O}_{2}$, and the noble metal catalyst. ${ }^{2}$

The hydroxyl radical $\left(\mathrm{HO}^{\bullet}\right)$ can be particularly detrimental to the polymer as it initiates degradation. $\mathrm{HO}^{\bullet}$ reacts with aromatic compounds with typical rate constants in the range of the diffusion limit of $10^{9}-10^{10} \mathrm{M}^{-1} \mathrm{~s}^{-1}$. ${ }^{3,4}$ However, the nature of follow-up reactions, intermediates and the associated kinetics are rarely considered. The final result of $\mathrm{HO}^{\bullet}$ attack may be chain oxidation (e.g., hydroxylation), crosslinking, or

\footnotetext{
${ }^{a}$ Electrochemistry Laboratory, Paul Scherrer Institut, 5232 Villigen PSI, Switzerland. E-mail: t.nolte@science.ru.nl

${ }^{b}$ Eidgenössische Technische Hochschule (ETH) Zurich, Laboratory of Inorganic Chemistry, Vladimir-Prelog-Weg 1, 8093 Zurich, Switzerland

$\dagger$ Electronic supplementary information (ESI) available. See DOI: 10.1039/c9cp05454e \$ Current address: Department of Environmental Science, Institute for Water and Wetland Research, Radboud University Nijmegen, 6500 GL Nijmegen, The Netherlands.
}

chain fragmentation. ${ }^{5}$ These different mechanisms of polymer aging depend on the chemistry of the polymer. Thus, strategies to prevent aging ought to take these pathways into account (Fig. 1). For example, 'repairing' intermediates formed upon radical attack may be accomplished with suitable additives, i.e., antioxidants (e.g. in Fig. 1, reaction 11). ${ }^{6}$

There is an analogy to oxidative stress in living cells: here, it is the characteristic of imbalance between reactive oxygen species (ROS) generation and an organism's endogenous defenses. $\mathrm{OH}^{\bullet}$ is generated from 'leakage' of electrons along the cellular electron transport chain, and can react with cell constituents (DNA, proteins). As a consequence, oxidative stress is the basis of many serious diseases such as cancer. Nature has its way of detoxifying radicals, i.e., using vitamins and enzymes. When these endogenous mechanisms to combat oxidative stress fall short, we can consider treatment via synthetic alternatives. Ceria nanoparticles (CNPs) are promising inorganic antioxidants for many biomedical applications. CNPs have demonstrated antioxidant enzyme-mimetic activity, as well as the capacity to scavenge a variety of ROS in both cell and animal models. Concomitantly, a reduction in DNA damage (e.g. in lung cells) has been observed. ${ }^{7}$ Cerium ions or ceria particles are also used to mitigate degradation in PFSA-type fuel cell membranes ${ }^{8}$ via direct scavenging of $\mathrm{OH}^{\bullet}$, and potentially $\mathrm{H}^{\bullet}:^{9,10}$

$$
\mathrm{Ce}^{3+}+\mathrm{HO}^{\bullet}+\mathrm{H}^{+} \rightarrow \mathrm{Ce}^{4+}+\mathrm{H}_{2} \mathrm{O} \quad\left(k_{1}=3 \times 10^{8} \mathrm{M}^{-1} \mathrm{~s}^{-13}\right)
$$




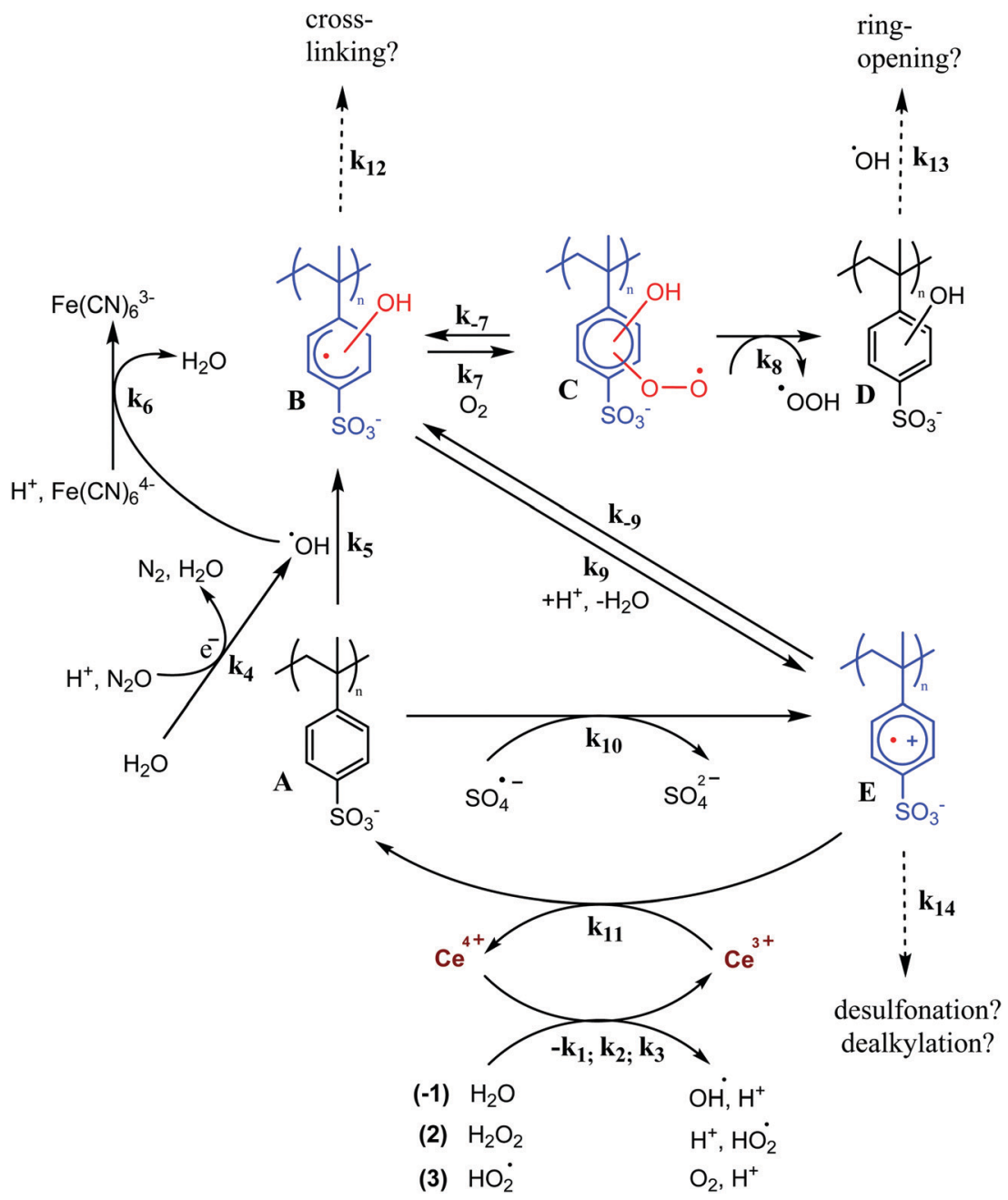

Fig. 1 Reaction pathways considered in this study. Reaction between the PAMSS polymer/oligomer (compound A) with $\mathrm{OH}$ (reaction 5), produces a hydroxycyclohexadienyl adduct (compound B). This adduct can undergo (acid-catalyzed) elimination of $\mathrm{H}_{2} \mathrm{O}$ (reaction 4) to produce a radical cation (compound E). Short-lived intermediates of PAMSS ( $\leqslant 1 \mathrm{~ms}$ ) are indicated in color. The aim of this study is to determine whether Ce ${ }^{3+}$ is a competitive repair agent for the radical cation (reaction 11), in terms of side reactions (reaction 7, 8 and 12-14).

The antioxidant properties of CNPs are dependent, also, on the ability to undergo redox cycling between the valences $\mathrm{Ce}^{3+}$ and $\mathrm{Ce}^{4+}$ ions (as $\mathrm{CeO}_{2-\delta}$ ) on the surface of $\mathrm{CeO}_{2}$ or $\mathrm{Ce}_{2} \mathrm{O}_{3} \mathrm{CNPs}$ in aqueous solution. ${ }^{11}$ Radical scavenging by $\mathrm{Ce}^{3+}$ is very effective in PFSA membranes, because the lifetime of $\mathrm{HO}^{\bullet}$ is on the order of microseconds, thus with a relatively small concentration of $\mathrm{Ce}^{3+}$ of $\sim 0.1 \mathrm{M}$ over $90 \%$ of $\mathrm{HO}^{\bullet}$ are quenched. ${ }^{5}$ The ratio of $\mathrm{Ce}^{4+}$ to $\mathrm{Ce}^{3+}$ is influenced by the chemistry of the medium. For example, $\mathrm{H}_{2} \mathrm{O}_{2}$ and $\mathrm{HO}_{2}{ }^{\circ}$, which are also present in a fuel cell membrane, ${ }^{12}$ can reduce $\mathrm{Ce}^{4+}$ to $\mathrm{Ce}^{3+}::^{13}$

$$
\begin{gathered}
\mathrm{Ce}^{4+}+\mathrm{H}_{2} \mathrm{O}_{2} \rightarrow \mathrm{Ce}^{3+}+\mathrm{HO}_{2}^{\bullet}+\mathrm{H}^{+} \quad\left(k_{2}=1 \times 10^{6} \mathrm{M}^{-1} \mathrm{~s}^{-18,14}\right) \\
\mathrm{Ce}^{4+}+\mathrm{HO}_{2}^{\bullet} \rightarrow \mathrm{Ce}^{3+}+\mathrm{O}_{2}+\mathrm{H}^{+} \quad\left(k_{3}=2.7 \times 10^{6} \mathrm{M}^{-1} \mathrm{~s}^{-114}\right)
\end{gathered}
$$

Because the $\mathrm{Ce}^{4+}$ that is formed reacts with $\mathrm{H}_{2} \mathrm{O}_{2}$ and $\mathrm{HOO}^{\circ}$, the scavenger $\mathrm{Ce}^{3+}$ can effectively be restored. Thus, these regenerative reactions enable a more effective catalytic $\mathrm{HO}^{\circ}$ scavenging mechanism by $\mathrm{Ce}^{3+}$. In polyaromatic fuel cell membranes, however, owing to the very fast reaction with the aromatic units, the lifetime of $\mathrm{HO}^{\bullet}$ is in the nanosecond range, thus around 3 orders of magnitude shorter than in PFSA membranes. Therefore, protecting polyaromatic polymers by scavenging of $\mathrm{HO}^{\bullet}$ alone is not sufficient. ${ }^{6}$ Nevertheless, we might exploit the redox cycling mechanism of Ce that forms the basis of its medicinal properties: we propose to use the $\mathrm{Ce}^{3+} / \mathrm{Ce}^{4+}$ redox couple to 'repair' the damage to polyarylene type ionomers caused by attack of the $\mathrm{OH}^{\bullet}$ radical. The question in this context is, given the chemistry of the polymer: does an intermediate exist that is sufficiently long-lived to be amenable to repair?

An intermediate formed as a result of $\mathrm{OH}^{\bullet}$ attack on arylenes is the aromatic radical cation $\left(\mathrm{Ar}^{0^{+}}\right)$(compound E, Fig. 1), produced by acid-catalyzed elimination of $\mathrm{H}_{2} \mathrm{O}$ (reaction 9, Fig. 1) from the $\mathrm{OH}$-adduct (compound B, Fig. 1). ${ }^{15,16}$ Since proton exchange membrane fuel cells operate under acidic 
conditions, elimination of $\mathrm{H}_{2} \mathrm{O}$ is usually fast. ${ }^{15-17}$ The redox potential $E^{\circ}$ of $\mathrm{Ce}^{4+} / \mathrm{Ce}^{3+}$ of $1.44 \mathrm{~V}^{18}$ is favorable as compared to $E^{\circ}\left(\mathrm{Ar}^{\bullet+} / \mathrm{Ar}\right)=2.0-2.4 \mathrm{~V}^{19}$ In previous work using poly( $\alpha$-methylstyrene sulfonate) (PAMSS) oligomers as model aromatic compound, we found that the lifetime of the radical cation increases with the degree of polymerization, potentially due to $\pi-\pi$ interactions, and does not produce benzyl radicals due to the presence of the $\alpha$-methyl group. ${ }^{20}$ PAMSS is well soluble in water making it a viable candidate to study the kinetics of its reaction with $\mathrm{Ce}^{3+}$ in aquo. PAMSS represents a constituent of a fuel cell membrane. Though other model compounds representing polyarylene type polymers (e.g. polysulfones) are conceivable, they are beyond the current scope.

In the work reported here, we studied the interaction (reaction 11, Fig. 1) between $\mathrm{Ce}^{3+}$ and the aromatic radical cation of PAMSS (compound $\mathbf{E}$ ) to investigate whether cerium could function as a regenerative antioxidant for repairing aryltype polymers. To determine whether the repair pathway is viable we compared the regeneration kinetics with a potential side reaction, prominently, the reaction of the HO-adduct (compound B) with $\mathrm{O}_{2}$ (reactions $7 /-7$ and 8, Fig. 1). The degree of polymerization of PAMSS was varied from 1 to 1700 in order to study the effect of $\mathrm{Ar}^{\bullet+}$ lifetime and redox properties. The results of this study are of high relevance to material scientists and engineers looking to improve the durability of hydrocarbon based fuel cell membranes, as well as for medicinists aiming to elucidate and optimize antioxidant mechanisms.

\section{Materials and methods}

PAMSS oligomers/polymers ( $>95 \%$ sulfonation degrees) with molecular weights $M_{\mathrm{w}}$ of 2660, 14600,73800 and $354000 \mathrm{Da}$, and polydispersity indices of $<1.5,<1.2,<1.2$ and $<1.2$, respectively, were supplied by PSS (Polymer Standards Service, Mainz, Germany). A 'monomeric unit' of PAMSS, 4-tert-butylbenzenesulfonate, was used to represent a 'degree of polymerization' of $1 . \mathrm{Ce}^{3+}$ was added as a salt, $\mathrm{Ce}_{2}\left(\mathrm{SO}_{4}\right)_{3}$, obtained from Sigma-Aldrich ( $\geq 99.99 \%$ purity). Water from a Millipore-Q system was used to prepare solutions that were saturated with $\mathrm{O}_{2}, \mathrm{~N}_{2} \mathrm{O}$, or Ar depending on the reaction studied. Samples were gas saturated in Schlenk-tubes which were repeatedly evacuated to 10 mbar and refilled (a minimum of 3 repeats) with the desired gas. The solutions were transferred from a gas-tight syringe (10 ml, Hamilton, SampleLock, Bonaduz, Switzerland) to the measurement cell via a syringe pump. Acidic $\mathrm{pH}$ was adjusted with $\mathrm{H}_{2} \mathrm{SO}_{4}$ (95-97\% purity), while solutions at $\mathrm{pH} 7$ were buffered with $0.1 \mathrm{mM}$ phosphate buffer $\left(\mathrm{NaH}_{2} \mathrm{PO}_{4} \cdot \mathrm{H}_{2} \mathrm{O}\right.$, $>99 \%$ purity), unless stated otherwise. Experiments were carried out at room temperature $\left(25^{\circ} \mathrm{C}\right)$. tert-Butanol was obtained from Merck (Darmstadt, Germany) to scavenge $\mathrm{OH}^{\bullet}$ when needed.

\section{Pulse radiolysis}

Pulse radiolysis experiments were carried out using a Febetron 705 (Titan Systems Corp., presently L-3 Communications,
San Leandro, CA, USA), equipped with an optical detection system. For details see Nauser et al. (2008). ${ }^{21}$ Irradiations were performed in a $6 \mathrm{~cm}$ quartz cell (Hellma, Müllheim, Germany) with $<50 \mathrm{~ns}$ pulses of $2 \mathrm{MeV}$ electrons. The dose was measured using a thiocyanate dosimeter.

\section{Production of $\mathrm{OH}^{\bullet}$ radicals}

Pulse irradiation of water results in the formation of primary species with yields $G\left(\mathrm{OH}^{\bullet}\right)$ (primary yield (molecules per $100 \mathrm{eV}$ ), $\mathrm{pH} 7), G\left(\mathrm{e}_{\mathrm{aq}}{ }^{-}\right)$and $G\left(\mathrm{H}^{\bullet}\right)$ of $2.7,2.65$ and $0.6,{ }^{22-24}$ respectively, whereby $G=1$ equals to $0.1036 \mu \mathrm{mol}$ of a species generated species per $1 \mathrm{~J} \mathrm{~kg}^{-1}$ absorbed energy. The solutions were saturated with $\mathrm{N}_{2} \mathrm{O}(22 \mathrm{mM})$ to increase the $\mathrm{OH}^{\bullet}$ yield and reduce side reactions. The solvated electron, $\mathrm{e}_{\mathrm{aq}}{ }^{-}$, reacts with $\mathrm{N}_{2} \mathrm{O}$ to yield additional $\mathrm{OH}^{\bullet}$ :

$$
\begin{gathered}
\mathrm{N}_{2} \mathrm{O}+\mathrm{e}_{\mathrm{aq}}{ }^{-}+\mathrm{H}_{2} \mathrm{O} \rightarrow \mathrm{N}_{2}+\mathrm{OH}^{\bullet}+\mathrm{OH}^{-} \\
\left(k_{4}=9.1 \times 10^{9} \mathrm{M}^{-1} \mathrm{~s}^{-123}\right)
\end{gathered}
$$

\section{Reaction of $\mathrm{OH}^{\bullet}$ with PAMSS}

Reaction of $\mathrm{OH}^{\bullet}$ with an aromatic unit (Fig. 1, reaction 5) produces a hydroxycyclohexadienyl adduct (Fig. 1, compound B). ${ }^{20,25}$ Here, we quantified the rate constants for the reaction between the polymers and $\mathrm{OH}^{\bullet}$ :

$$
\mathrm{OH}^{\bullet}+\mathrm{PAMSS} \rightarrow \operatorname{PAMSS}(-\mathrm{OH})^{\bullet}\left(k_{5}\right)
$$

PAMSS radicals have relatively low extinction coefficients and side-reactions might be involved at high concentrations of radicals. To bypass and minimize this, we studied the reaction with $\mathrm{OH}^{\bullet}$ via competition with $\mathrm{Fe}(\mathrm{CN})_{6}{ }^{4-}$ :

$$
\begin{gathered}
\mathrm{OH}^{\bullet}+\mathrm{Fe}(\mathrm{CN})_{6}{ }^{4-} \rightarrow \mathrm{OH}^{-}+\mathrm{Fe}(\mathrm{CN})_{6}{ }^{3-} \\
\left(k_{6}=1.05 \times 10^{10} \mathrm{M}^{-1} \mathrm{~s}^{-1}\right)
\end{gathered}
$$

At relatively low dose $(\sim 10 \mathrm{~Gy})$, the concentration of $\mathrm{Fe}(\mathrm{CN})_{6}{ }^{4-}$ was $\sim 50 \mu \mathrm{M}$ and the concentration of PAMSS was varied. Under $\mathrm{N}_{2} \mathrm{O}$ saturated conditions the radiation chemical yield $(G)$ of $\mathrm{OH}^{\bullet}$ is $\sim 5.6 \times 10^{-7} \mathrm{~mol} \mathrm{~J}^{-1}$ and is unaffected by the PAMSS concentration (dilute solutions, $\leq 100 \mu \mathrm{M}$ ). Thereby, the absorbance at $420 \mathrm{~nm}\left(\mathrm{Fe}(\mathrm{CN})_{6}{ }^{3-}, \varepsilon_{420}=1040 \mathrm{M}^{-1} \mathrm{~cm}^{-1}\right)$ is solely affected by the PAMSS concentration via competition for $\mathrm{OH}^{\bullet}$. The absorption at $420 \mathrm{~nm}$, virtually constant after $\sim 5 \mu \mathrm{s}$, was measured.

Control experiments were performed using different dose/ $\mathrm{Fe}(\mathrm{CN})_{6}{ }^{4-}$ ratios, as well as direct observation (details in the $\mathrm{ESI} \dagger)$.

\section{Reaction of hydroxycyclohexadienyl radicals with oxygen}

Reaction of $\mathrm{O}_{2}$ with hydroxycyclohexadienyl radicals (Fig. 1, reaction 7) produces an $\mathrm{Ar}-\mathrm{OH}\left(-\mathrm{O}_{2}\right)$ radical adduct (Fig. 1, compound $\mathbf{C}$ ):

$$
\operatorname{PAMSS}(-\mathrm{OH})^{\bullet}+\mathrm{O}_{2} \rightleftharpoons \operatorname{PAMSS}(-\mathrm{OH})\left(-\mathrm{O}_{2}\right)^{\bullet} \quad\left(k_{7} / k_{-7}\right)
$$

The addition of $\mathrm{O}_{2}$ to hydroxycyclohexadienyl radicals was studied by varying the $\mathrm{O}_{2}$ concentration, and observing the 

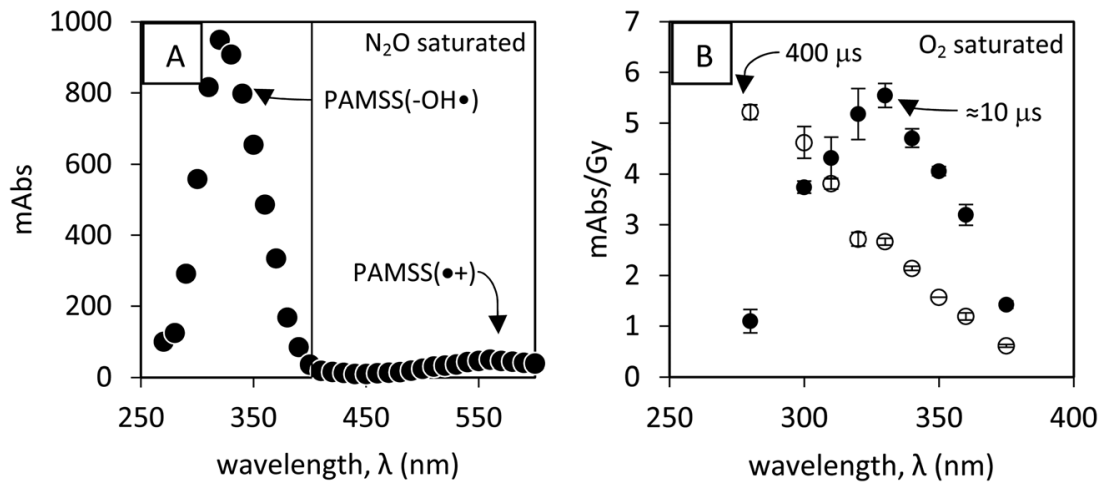

Fig. 2 (A) Spectrum of $5 \mu \mathrm{M}$ poly ( $\alpha$-methylstyrene sulfonate) $M_{w}=354000$ Da. Dose $\sim 15 \mathrm{~Gy}, \mathrm{~N}_{2} \mathrm{O}$ saturated, $\mathrm{pH} \sim 7$. The absorption was highest within the time interval of the first $10 \mu \mathrm{s}$ after the pulse. (B) Spectrum of $32.7 \mu \mathrm{M}$ poly $\left(\alpha\right.$-methylstyrene sulfonate) $M_{\mathrm{w}}=14600 \mathrm{Da}$. Dose $\sim 50 \mathrm{~Gy}, \mathrm{O}_{2}$ saturated $(1.25 \mathrm{mM}), \mathrm{pH} \sim 7$. Highest within $10 \mu \mathrm{s}$ (filled symbols, see Fig. S8-1A, ESI $\dagger$ ) and $400 \mu \mathrm{s}$ (open symbols) after the pulse. Absorbances <280 nm are omitted because optimization of spectral resolution at the expense of incident light intensity resulted in noisy and inaccurate absorbance.

effect on the kinetic trace of hydroxycyclohexadienyl radicals. Mixtures of $\mathrm{N}_{2} \mathrm{O} / \mathrm{O}_{2}$ were used and the concentration of $\mathrm{O}_{2}$ in the samples was determined via the partial pressure of $\mathrm{O}_{2}$ and its solubility in water $(1.25 \mathrm{mM}$ at $1.0 \mathrm{~atm}) . \mathrm{O}_{2}$ concentrations ranged from 0 to $1.25 \mathrm{mM}$. Doses applied were $\sim 40 \mathrm{~Gy}$. All experiments reported were reproduced at least five times.

The characteristic $\lambda_{\max }$ for hydroxycyclohexadienyl-type radicals is $\sim 325 \mathrm{~nm}$, Fig. 2. However, other species, among which the $\operatorname{Ar}-\mathrm{OH}\left(-\mathrm{O}_{2}\right)$ radical adduct, absorbs also in this spectral range (Fig. 2B). Moreover, the addition of oxygen is reversible ${ }^{25}$ with an equilibrium constant $K$ on the order of $\geq 10^{3} \mathrm{M}^{-1},{ }^{25}$ because the reverse reaction is relatively slow (reaction -7 , Fig. 1, with $k_{-7}=4.5( \pm 0.9) \times 10^{3} \mathrm{~s}^{-1}$ as an upper limit for poly(styrene sulfonate) (PSS) ${ }^{26}$ ).

The addition reaction was monitored at $\lambda=360 \mathrm{~nm}$, chosen empirically such that both the relative absorption of the $\mathrm{OH}^{\bullet}$ adduct (relative to the $\mathrm{Ar}-\mathrm{OH}\left(-\mathrm{O}_{2}\right)$ adduct) and absolute absorption are maximized (Fig. S4B, ESI $\dagger$ ). Based on earlier results $^{25,26}$ we identified the decay within $\sim 10-20 \mu$ s of the absorption maximum. The kinetic traces were fitted with pseudo-first order functions. This analytical setup minimized the need of fitting to equilibria or taking into account side reactions, such as ${ }^{\bullet} \mathrm{OOH}$ elimination (reaction 8 , Fig. 1 , with $k_{8}=2.7( \pm 0.3) \times 10^{3} \mathrm{~s}^{-1}$ for $\left.\mathrm{PSS}^{18}\right)$ to form a stable hydroxylated product (compound $\mathbf{D}$ ). Thus, we can fit kinetic traces for the $\mathrm{OH}^{\bullet}$-adduct with minimal interference. ${ }^{25}$

Control experiments were performed using gas mixtures of Argon $/ \mathrm{O}_{2}$ and $\mathrm{N}_{2} \mathrm{O} / \mathrm{O}_{2}$ under low doses $(\sim 10 \mathrm{~Gy})$ to characterize the relevance of the yield of $\mathrm{OH}$-adducts (details in Fig. S8, ESI $\dagger$ ) on the apparent rate constants.

\section{Production of radical cations and reaction with $\mathrm{Ce}^{3+}$}

Under $\mathrm{N}_{2} \mathrm{O} / \mathrm{O}_{2}$ conditions and $\mathrm{pH} \sim 7$ the yield of radical cations from $\mathrm{OH}^{\bullet}$-adducts (e.g. via reaction 9, Fig. 1) is low: $0.1-1 \mu \mathrm{M}$ for $M_{\mathrm{w}}=354000 \mathrm{Da}$ (Fig. $2 \mathrm{~A}, \lambda_{\max } \cong 560 \mathrm{~nm}$ ), and below our detection limit for smaller polymer weights. When the radical cation was produced at $\mathrm{pH} \sim 7$ via elimination from the PAMSS-OH ${ }^{\bullet}$ adduct $\left(M_{\mathrm{w}}=354000 \mathrm{Da}\right)$, no reaction between the radical cation and $\mathrm{Ce}^{3+}$ was observed.
Rate constants for the elimination of $\mathrm{OH}^{-} / \mathrm{H}_{2} \mathrm{O}$ have previously been identified as $\sim 10^{4} \mathrm{~s}^{-1}$ for a range of aryl-type $\mathrm{OH}^{\bullet}$-adducts, ${ }^{16}$ whereas for the reaction between radical cation and $\mathrm{H}_{2} \mathrm{O}$ (reaction -9 , Fig. 1 ) values differ $10^{1}-10^{716}\left(k_{-9}=\right.$ $1-2 \times 10^{4} \mathrm{~s}^{-1}$, Fig. 5 and Fig. S10-S12, ESI $\left.\dagger\right)$. Thus, simultaneous production of radical cations via elimination (reaction 9 , Fig. 1) from the PAMSS-OH ${ }^{\bullet}$ adduct (Fig. 2A) might obscure the depletion via reaction with $\mathrm{Ce}^{3+}$ (reaction 11, Fig. 1).

Bypassing the $\mathrm{H}_{2} \mathrm{O} / \mathrm{OH}^{-}$elimination from PAMSS-OH ${ }^{*}$ route, radical cations were produced by electron transfer to sulfate radicals (reaction 10, Fig. 1):

$$
\begin{gathered}
\text { PAMSS }+\mathrm{SO}_{4}{ }^{--} \rightarrow \mathrm{PAMSS}^{\bullet+}+\mathrm{SO}_{4}{ }^{2-} \\
\left(k_{10}=0.6-1.0 \times 10^{9} \mathrm{M}^{-1} \mathrm{~s}^{-120}\right)
\end{gathered}
$$

Potassium peroxodisulfatesulfate $(50 \mathrm{mM})$ was added to argon-saturated solutions at $\mathrm{pH} \sim 2$ (adjusted with $\mathrm{H}_{2} \mathrm{SO}_{4}$ ). Dose was $\sim 100 \mathrm{~Gy}$, and $t \mathrm{BuOH}(100 \mathrm{mM})$ was added to scavenge the primary $\mathrm{OH}^{\bullet}$ radicals. Concentrations of PAMSS were used according to the degree of polymerization (e.g. $4.5 \mathrm{mM}$ for PAMSS-354 000). We varied the $\mathrm{Ce}^{3+}$ concentration to obtain pseudo first-order rate constants for the reaction:

$$
\mathrm{Ce}^{3+}+\mathrm{PAMSS}^{\bullet+} \rightarrow \mathrm{Ce}^{4+}+\text { PAMSS }\left(k_{11}\right)
$$

\section{Results and discussion}

\section{Reaction of $\mathrm{OH}^{\bullet}$ with PAMSS}

The introduction of PAMSS to a solution containing $\mathrm{Fe}(\mathrm{CN})_{6}{ }^{3-}$ led to a decrease in the absorption recorded at $420 \mathrm{~nm}$ (i.e. reaction between $\mathrm{Fe}(\mathrm{CN})_{6}{ }^{3-}$ and $\left.\mathrm{OH}^{*}\right)$. This is indicative of a reaction between $\mathrm{OH}^{\bullet}$ and PAMSS (i.e. a competition for $\mathrm{OH}^{\bullet}$ ). Taking into account reaction 6 (Fig. $1, \mathrm{Fe}(\mathrm{CN})_{6}{ }^{3-}+\mathrm{OH}^{\bullet}$ ) we fitted the data (blue lines and triangles in Fig. 3) to obtain $k_{5}=5.7( \pm 0.2) \times 10^{11} \mathrm{M}^{-1} \mathrm{~s}^{-1}$ for the bimolecular reaction rate constant between PAMSS-354 000 (the polymer with the highest $M_{\mathrm{w}}$ ) and $\mathrm{OH}^{\bullet}$ (Fig. 1, reaction 5). By extension, we obtained the following data for the series of oligomers/polymers with different molecular weight, given in Table 1. 

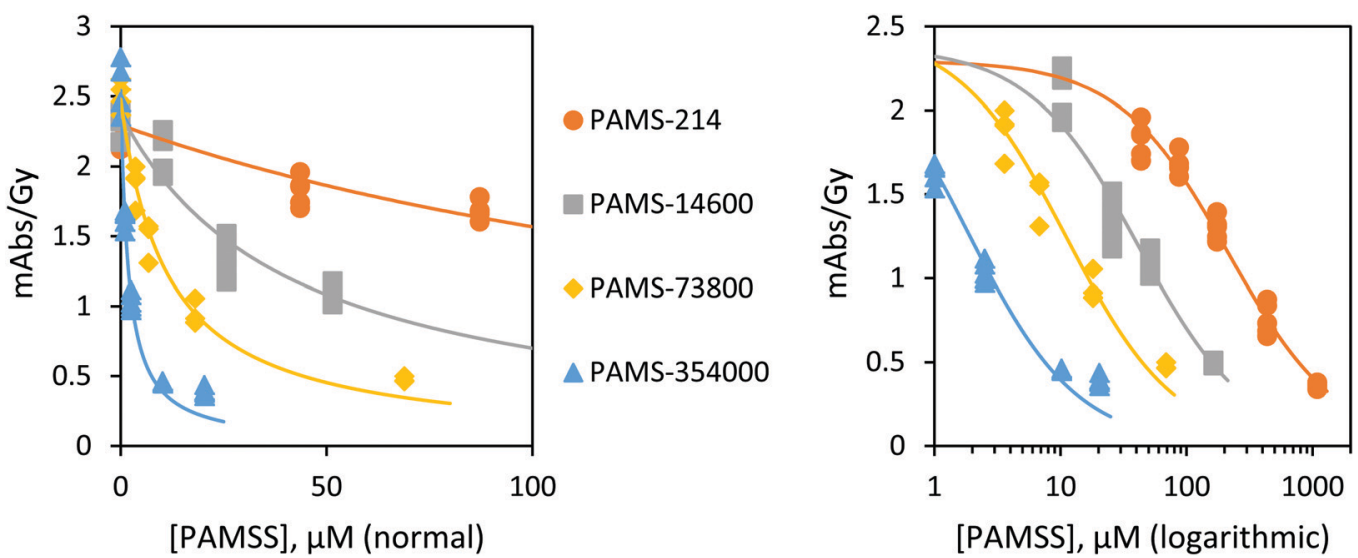

Fig. 3 The determination of the reaction rate constant between PAMSS and $\mathrm{OH}^{\bullet}$ via competition with $\mathrm{Fe}\left(\mathrm{CN}_{6}\right)^{3-}$. The $\mathrm{Fe}\left(\mathrm{CN}_{6}\right)^{3-} \mathrm{COncentration}$ was approximately $100 \mu \mathrm{M}$. Dose $\sim 25 \mathrm{~Gy}$. Lines denote fitting based on competition kinetics.

Table 1 Rate constants for the reaction between $\mathrm{OH}^{\bullet}$ and PAMSS polymers/oligomers (c.k. = competition kinetics)

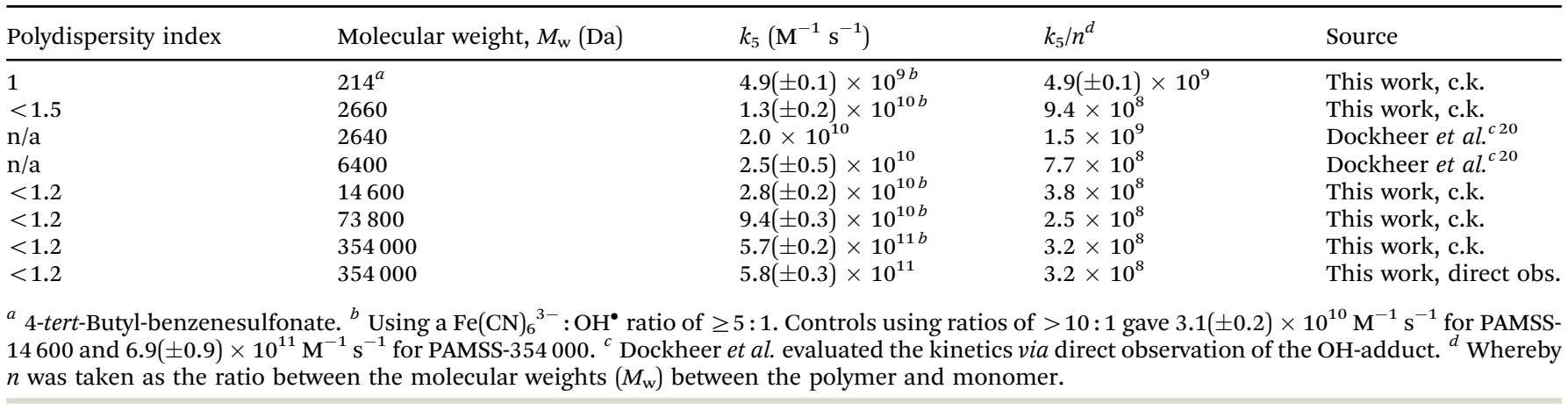

The apparent yield of adducts (absorption at $360 \mathrm{~nm}$ ) under $\mathrm{N}_{2} \mathrm{O}$ atmosphere is less than twice that obtained under $\mathrm{O}_{2}$ (3.2 and 5.9 abs $\mathrm{Gy}^{-1}$, resp.), i.e. $G\left(\mathrm{~N}_{2} \mathrm{O}\right) / G\left(\mathrm{O}_{2}\right)=1.86 \pm 0.04$ (Fig. 4A). The ratio in yields of the primary radicals, $G\left(\mathrm{OH}^{\bullet}\right.$, $\left.\mathrm{N}_{2} \mathrm{O}\right)+G\left(\mathrm{H}^{\bullet}, \mathrm{N}_{2} \mathrm{O}\right)=0.622$ and $G\left(\mathrm{OH}^{\bullet}, \mathrm{O}_{2}\right)+G\left(\mathrm{H}^{\bullet}, \mathrm{O}_{2}\right)=0.342$, i.e. $G\left(\mathrm{~N}_{2} \mathrm{O}\right) / \mathrm{G}\left(\mathrm{O}_{2}\right)=1.82$, is similar. We infer that the absorption corresponds to $5-10 \%$ PAMSS- $\mathrm{H}^{\bullet}$ adducts. Nevertheless, measurement of $k_{5}$ via direct observation produced the same value as obtained via competition kinetics (Table 1), Fig. S1 (ESI $\dagger$ ). The suite of control studies indicated the stability of the method (Table 1).

We obtained larger values for $k_{5}$ for larger molecular weights. However, when we express $k_{5}$ per monomer unit, there is a notable decrease. The data match earlier observations by, e.g., Dockheer $e t$ al. $^{20}$ for a more limited range of $M_{\mathrm{w}}$ (Table 1); we find our values either slightly lower or equal to what has been reported.

The influence of size could be expressed as $k_{5} \sim[n]^{0.60 \pm 0.08}$ $\left(k_{5} \sim[n]^{0.57}\right.$ including Dockheer et al. data, ${ }^{20}$ Fig. 6), wherein $[n]$ is the degree of polymerization. Variation in the polydispersity index (PDI) between the polymers is not expected to influence the relationships obtained in this study (since PDI $<1.2$ ). The "reaction exponent", here $0.60 \pm 0.08$, is sometimes defined as $\theta::^{27,28}$

$$
\theta=\frac{(3+g)}{z}
$$

In case the polymer dynamics are 'Rouse-like' (single un-entangled chain; no significant interactions between chain segments) $z=4$. In turn, $g=0$ represents a non-interacting electron-electron system (the correlation hole ${ }^{29}$ is screened out). Then, the reaction exponent is $(3+0) / 4=0.75$. Indeed, $k_{5}$ values are near the "diffusion control": $k_{5} \sim[n]^{0.60}$, i.e. $0.60 \pm 0.08 \lesssim 0.75$. Thus, $k_{\mathrm{r}}$ is largely independent of the reactivity of the reaction site.

\section{Decay of hydroxycyclohexadienyl radicals}

The first order decay of PAMSS-OH ${ }^{\bullet}$ seems to be a function of the yield of $\mathrm{OH}^{\bullet}$-adducts (Fig. $\mathrm{S} 3$ and $\mathrm{S} 8, \mathrm{ESI} \dagger$ ). If we assume the yield of $\mathrm{OH}^{\bullet}$-adducts is 8 times larger under 40 Gy and $\mathrm{N}_{2} \mathrm{O}$, as compared to under $10 \mathrm{~Gy}$ and argon, we derive based on Fig. S3 and S8 (ESI $\dagger$ ) a slope (rate constant) on the order of $5( \pm 1) \times 10^{2} \mathrm{M}^{-1} \mathrm{~s}^{-1}$ (Fig. S3, ESI $\dagger$ ). The intercept is $2.2( \pm 0.5) \times$ $10^{3} \mathrm{~s}^{-1}$ (Fig. S3, ESI $\dagger$ ). The half-life of the PAMSS-OH ${ }^{\bullet}$ adduct (as observable at $\sim 325 \mathrm{~nm}$ ) generally increased with $M_{\mathrm{W}}$ (e.g. $k_{\mathrm{obs}}=1.4( \pm 0.3) \times 10^{4} \mathrm{~s}^{-1}$ and $6.1( \pm 0.3) \times 10^{3} \mathrm{~s}^{-1}$ for $M_{\mathrm{W}}=2660$ and 14600 , resp.), though quantification requires the relative (effective) concentration of $\mathrm{OH}$-adducts for different $M_{\mathrm{W}}$. PAMSS-OH adducts seem to be more stable as the $M_{\mathrm{W}}$ increases.

A neighboring monomer might interact with the radical site in such a way that its intrinsic reactivity is lowered, or the 

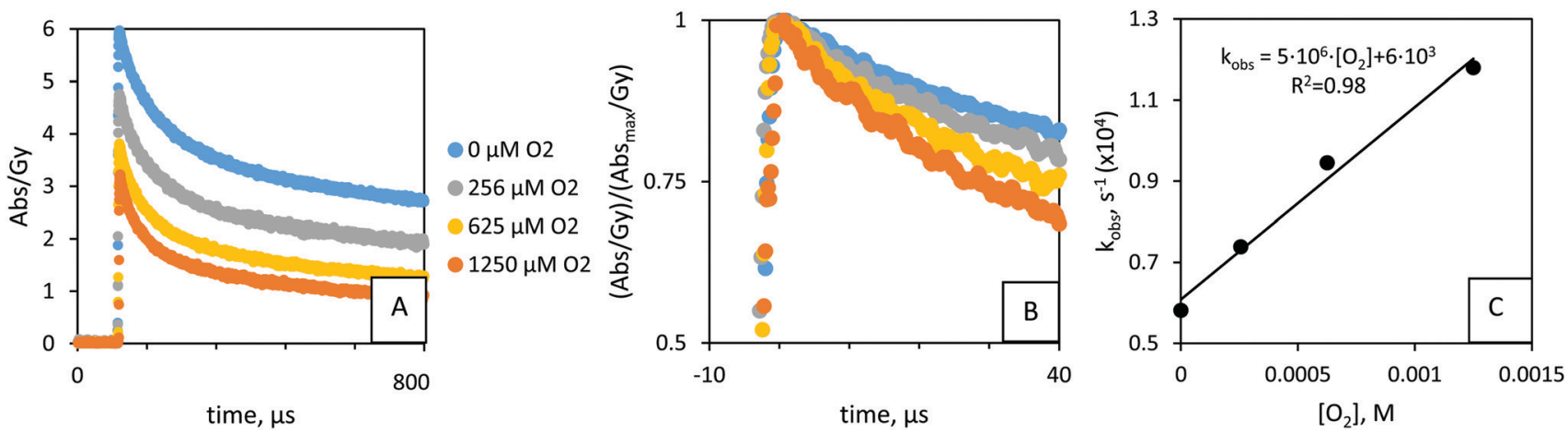

Fig. 4 (A) Kinetic traces for the reaction between (decay of) PAMSS-14600(-OH・) adduct and $\mathrm{O}_{2}$, monitored at $360 \mathrm{~nm}$. Time-averaged. $32.7 \mu \mathrm{M}$ PAMSS-14600, $\sim 25^{\circ} \mathrm{C}$. pH $\sim 7 ; 5$ replicates per data point. Colors show the concentration of $\mathrm{O}_{2}$ in $\mu$ M. (A) $\mathrm{N}_{2} \mathrm{O} / \mathrm{O}_{2}$ solutions., $\sim 40$ Gy. Long time interval. (B) $\mathrm{N}_{2} \mathrm{O} / \mathrm{O}_{2}$ solutions. $\sim 40 \mathrm{~Gy}$. Short time interval; normalized by the absorption at $t_{0}(\sim 2 \mu \mathrm{s})$. (C) $\mathrm{N}_{2} \mathrm{O} / \mathrm{O}_{2}$ solutions. $\sim 40$ Gy. Pseudo 1 st order rate constants versus $\mathrm{O}_{2}$ concentration. $k_{7}=4.8( \pm 0.4) \times 10^{6} \mathrm{M}^{-1} \mathrm{~s}^{-1}$.

coiling of the polymer chain may decrease its accessibility. Values for propagation in radical polymerisations are typically $10^{3 \pm 1} \mathrm{M}^{-1} \mathrm{~s}^{-1}, 30$ i.e. slow due to steric crowding about the radical center. Based on this, we consider the value $5( \pm 1) \times$ $10^{2} \mathrm{M}^{-1} \mathrm{~s}^{-1}$ to correspond to reaction 12 (crosslinking and/or disproportionation, $k_{12}$ ) in Fig. 1 .

Protonation of $\mathrm{OH}^{\bullet}$-adducts occurs with a rate constant of $k=1-2 \times 10^{9} \mathrm{M}^{-1} \mathrm{~s}^{-116}$ implying a pseudo 1 st order rate constant of $1-2 \times 10^{2} \mathrm{~s}^{-1}$ at $\mathrm{pH} 7$, whereas the elimination of $\mathrm{OH}^{-}$occurs with a rate on the order $\sim 10^{4} \mathrm{~s}^{-1}$ for a range of aryl-type $\mathrm{OH}^{\bullet}$-adduct monomers. ${ }^{16}$ Thus, the value of $2.2( \pm 0.5) \times$ $10^{3} \mathrm{~s}^{-1}$ might characterize reaction 9 (either elimination of $\mathrm{OH}^{-}$ or acid-catalysed elimination of $\left.\mathrm{H}_{2} \mathrm{O}, k_{9}\right)$ of PAMSS-14 $600\left(-\mathrm{OH}^{\bullet}\right)$ as denoted in Fig. 1, reaction 9/-9.

\section{Reaction of hydroxycyclohexadienyl radicals with oxygen}

Upon exposure of the hydroxycyclohexadienyl radicals to $\mathrm{O}_{2}$ we observed a shift to shorter wavelengths over time (Fig. 2B). $\sim 400 \mu \mathrm{s}$ after the pulse, there was no apparent contribution from the $\mathrm{OH}$-adduct (as seen at $\lambda_{\max }=325 \mathrm{~nm}$ ) to the absorbance anymore (Fig. 2B, see also ESI $\dagger$ ). The shift to shorter wavelength for reaction products under $\mathrm{O}_{2}$ atmosphere (Fig. 2B and Fig. S4-S6, ESI $\dagger$ ) has been observed in related studies ${ }^{20,25}$ and is attributed to $\mathrm{O}_{2}$-radical adducts.

The yield of $\mathrm{OH}^{*}$-adducts varied for different ratios of $\mathrm{N}_{2} \mathrm{O} / \mathrm{O}_{2}$ and between pulses (Fig. 4A); the concentration of $\mathrm{OH}^{\bullet}$-adducts under $\mathrm{N}_{2} \mathrm{O} / \mathrm{O}_{2}$ mixtures was directly proportional to the yield of $\mathrm{OH}^{\bullet}$, see Fig. $4 \mathrm{~A}$ and Fig. S7 (ESI $\dagger$ ). This was taken into account when evaluating the pseudo-first order reaction with $\mathrm{O}_{2}$ (reaction 7 , Fig. 1): ${ }^{24}$ we consider the relative concentrations of $\mathrm{OH}^{\bullet}$-adducts. Thus, Fig. 4A was corrected for the adduct yields (maximum absorbance, at $\sim 2 \mu \mathrm{s}$ ), to give Fig. 4B.

Control studies indicated the stability of the method (Fig. S8, $\mathrm{ESI} \dagger$ ): $\mathrm{H}^{\bullet}$ is quenched by PAMSS, rather than $\mathrm{O}_{2}$. There is no difference between the $k_{7}$ values obtained from series under argon or $\mathrm{N}_{2} \mathrm{O}$. Therefore, PAMSS- $14600\left(-\mathrm{H}^{\circ}\right)$ adducts react slower with $\mathrm{O}_{2}$ than do PAMSS-14 600(-OH') adducts and do not contribute significantly to the result. Different initial yields of
PAMSS-14 600(-OH ${ }^{\bullet}$ ) adducts (at $t=2 \mu \mathrm{s}$ ), do not appear to affect the results (Fig. 4C and Fig. S8, ESI $\dagger$ ). Thus, in the range of $2 \mu$ s to $10-20 \mu \mathrm{s}$, there is no measurable equilibration or elimination of $\mathrm{OOH}^{\bullet}$ yet. Compared to $1.25 \times 10^{-3} \mathrm{M}_{\text {for }} \mathrm{O}_{2}$ (in $\mathrm{O}_{2}$ saturated solutions), the experimental series may also yield superoxide, $\mathrm{O}_{2}{ }^{\bullet-}$ (Fig. S8-1A, ESI $\dagger$ ), in $10 \mu \mathrm{M}$ (higher-end estimation). In $\mathrm{O}_{2}$ saturated solutions $(\sim 1.25 \mathrm{mM}) G\left(\mathrm{OH}^{\bullet}\right) \sim 2.8 \times 10^{-7} \mathrm{~mol} \mathrm{~J}^{-1}$ and $G\left(\mathrm{O}_{2}{ }^{\cdot-}\right) \sim 3.4 \times 10^{-7} \mathrm{~mol} \mathrm{~J}^{-1}$. The reaction between PAMSS$\mathrm{OH}$ and $\mathrm{O}_{2}$ is thermodynamically favored (compared to that with $\left.\mathrm{O}_{2}{ }^{\bullet-}\right)$ based on the energies of their frontier orbitals: ${ }^{31} \mid E_{\text {SOMO }}\left(\mathrm{O}_{2}\right)$ $-E_{\text {SOMO }}\left(\right.$ PAMSS-OH $\left.^{\bullet}\right)|<| E_{\text {SOMO }}\left(\mathrm{O}_{2}{ }^{\bullet-}\right)-E_{\text {SOMO }}\left(\right.$ PAMSS-OH $\left.^{\bullet}\right) \mid$, i.e. $\Delta E \sim 0.4 \mathrm{eV}<\Delta E \sim 0.9 \mathrm{eV}$ (in-house calculation ${ }^{32-34}$ ). The influence of $\mathrm{O}_{2}{ }^{--}$has not been reported in related studies (under high $\mathrm{O}_{2}$ concentrations ${ }^{25}$ ). Thus, the reaction between $\mathrm{O}_{2}{ }^{--}$and PAMSS-OH is of minor importance, and the rate constants for addition of $\mathrm{O}_{2}$ obtained in this study can be considered accurate.

From fitting we obtained a rate constant $k_{7}=4.8( \pm 0.4) \times$ $10^{6} \mathrm{M}^{-1} \mathrm{~s}^{-1}$ for the reaction between PAMSS-14 $600\left(-\mathrm{OH}^{\bullet}\right)$ and $\mathrm{O}_{2}$ (see ESI $\dagger$ for other $M_{\mathrm{w}}$ ) in Fig. 4C. The reaction of a carboncentered radical with $\mathrm{O}_{2}$ to form the corresponding peroxyl radical generally proceeds with a rate constant on the order of $10^{9} \mathrm{M}^{-1} \mathrm{~s}^{-1} \cdot{ }^{35}$ However, because of electron delocalization in allylic and dienylic C-centered radicals, oxygen binds relatively weakly, which results in slower and reversible $\mathrm{O}_{2}$ addition. These notions are in agreement with the data obtained. Other factors explaining the relatively low rate constants include steric hindrance (tert-butyl) and polarity (sulfate) but need to be studied in more detail.

There appeared to be an influence of molecular weight, as a $k_{7}$ of $2.2( \pm 0.3) \times 10^{7} \mathrm{M}^{-1} \mathrm{~s}^{-1}$ was found for the 4-tert-butylbenzenesulfonate $\left(-\mathrm{OH}^{\bullet}\right)$ adduct. The data are in the same order as was found for PSS-1100 $\left(-\mathrm{OH}^{\circ}\right): k=3.0( \pm 0.5) \times 10^{7} .^{26}$ For the reaction between the $\mathrm{OH}^{\circ}$-adducts and $\mathrm{O}_{2}, k_{7}$ scales with $n: k_{7} \sim[n]^{-0.26 \pm 0.07}$. PSS data ${ }^{26}$ might be included in the analysis if no significant influence by the extra methyl group is expected on the reaction thermochemistry, relative to the effect of $M_{\mathrm{w}}$ (Fig. 6). The influence of polymer size on the reaction between PAMSS $\left(-\mathrm{OH}^{\bullet}\right)$ and $\mathrm{O}_{2}(-0.26 \pm 0.07)$ is different $(2 \sigma)$ from for the reaction between PAMSS and $\mathrm{OH}^{\bullet}(0.60 \pm 0.08)$. 
Since there is only 1 reactive site on the polymer, no relationship with $n\left(k_{7} \sim[n]^{0}\right)$ should be expected if diffusive or quantum-chemical effects are absent. Instead, the polymer dynamics i.e. diffusive pathway $(z)$ and/or quantum-chemical properties $(g)$ (eqn (10)) are affected $(<0)$ by the breaking of aromaticity by $\mathrm{OH}^{\bullet}$ to produce the hydroxycyclohexadienyl radical. It is worth noting that hydroxycyclohexadienyl radicals are relatively electron-rich and non-planar (Fig. 1, compound B), which would disfavor $\pi-\pi$ interaction.

\section{Decay of radical cations}

In argon-saturated conditions and $\mathrm{pH} \sim 2, \mathrm{SO}_{4}{ }^{--}$radicals were produced from the reaction between peroxodisulfate and the solvated electron. $\mathrm{SO}_{4}{ }^{\bullet-}$ radicals oxidize PAMSS to produce a radical cation observable at $560 \mathrm{~nm}$. We detected radical cations for $2600 \geq M_{\mathrm{w}} \geq 354000$, whereas for the 4-tert-butylbenzenesulfonate (i.e. the monomer unit) no radical cations could be observed. The half-life of the radical cation was found to be $\sim 40$ to $\sim 100 \mu$ s depending on the chain length (Fig. 5). The influence of size was reported earlier by Dockheer et al. for a more limited range of $M_{\mathrm{w}}{ }^{20}$

The radical cations showed longer lifetimes upon increasing the molecular weight of the polymer (Fig. 6 and Fig. S10 and S11, ESI $\dagger)$, with reaction exponents $\left(k \sim[n]^{0.09 \pm 0.03}\right)$ similar to those for the reaction between the radical cation and $\mathrm{Ce}^{3+}$
$(0.12 \pm 0.01)$. Extrapolation of the data recorded in absence of $\mathrm{O}_{2}$ (under Ar), using a power function in Fig. 6 results in $k=1.6 \times 10^{4} \mathrm{~s}^{-1}$ for the first-order decay of the 4-tertbutylbenzenesulfonate radical cation $(\sim 40 \mu$ s half-life). This is relatively low compared to simple arenes, or even tert-butylbenzene cations $\left(10^{5}-10^{6} \mathrm{~s}^{-116}\right)$. The mode of decay by the radical cations is uncertain. The $\alpha$-methyl group prevents formation of a benzyl radical via a proton elimination (splitting) reaction and, instead, elimination of the sulfate was suggested ${ }^{20}$ or dealkylation (scission), Fig. 1. The cation might react intramolecularly with a nearby monomer, ${ }^{16}$ requiring a $k$ of $10^{6}-10^{7} \mathrm{~s}^{-1}$. This is unlikely based on thermodynamic grounds, and it would likely result a shift in $\lambda_{\text {max }}$ (for a similar radical cation), which was not observed. A radical-radical reaction would involve rate constants in the range of $10^{8}-10^{9} \mathrm{M}^{-1} \mathrm{~s}^{-1}$ (diffusion-limited, no thermodynamic arguments). This mechanism does not explain the size dependence observed and the decay that is still observed at very low concentrations, $\sim 10^{4} \mathrm{~s}^{-1}$. Rate constants for addition of $\mathrm{H}_{2} \mathrm{O}$ to the radical cation (i.e. the backward reaction -9 , Fig. 1) to form the water adduct are on the order of $10^{2}-10^{3} \mathrm{M}^{-1} \mathrm{~s}^{-1} \cdot{ }^{16}$ The decay observed in acidic aqueous solution is given by $k=6 \times 10^{3}-6 \times 10^{4} \mathrm{~s}^{-1}$. Addition of $\mathrm{H}_{2} \mathrm{O}$ to the radical cation would occur via direction of the lone pair into the SOMO of the radical cation. The cation, and by extension the energy of this SOMO, could be subject to
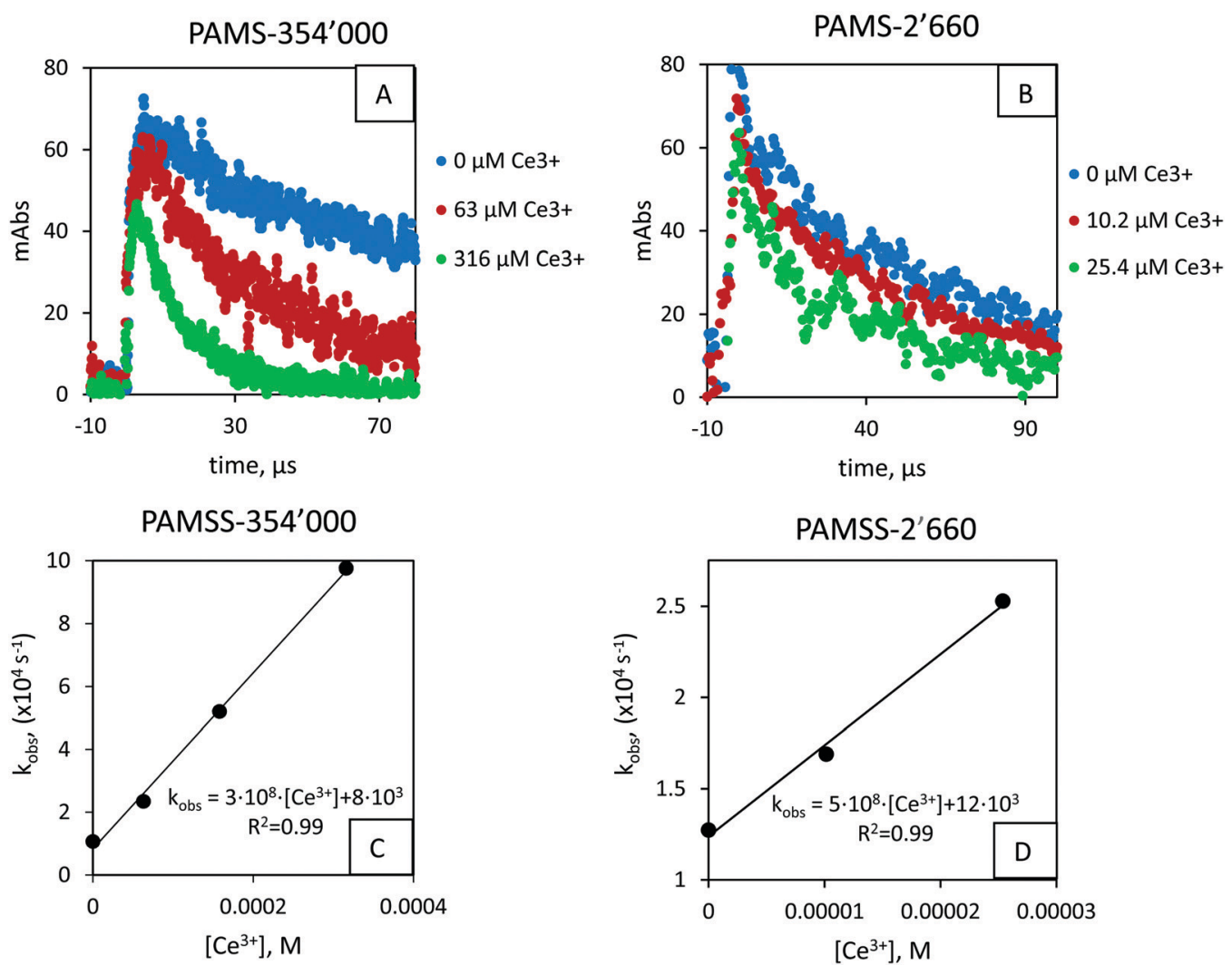

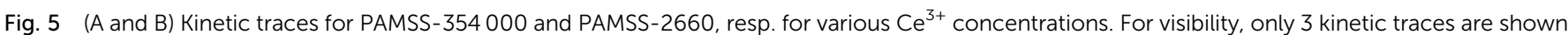

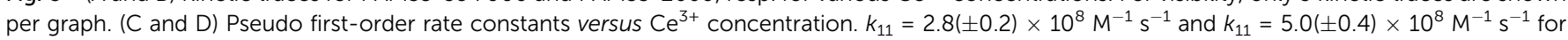
PAMSS-354 000 and PAMSS-2660, resp. Data for $M_{\mathrm{W}}=14600$ and $M_{\mathrm{W}}=73800$ can be found in the ESI. $\dagger$ 


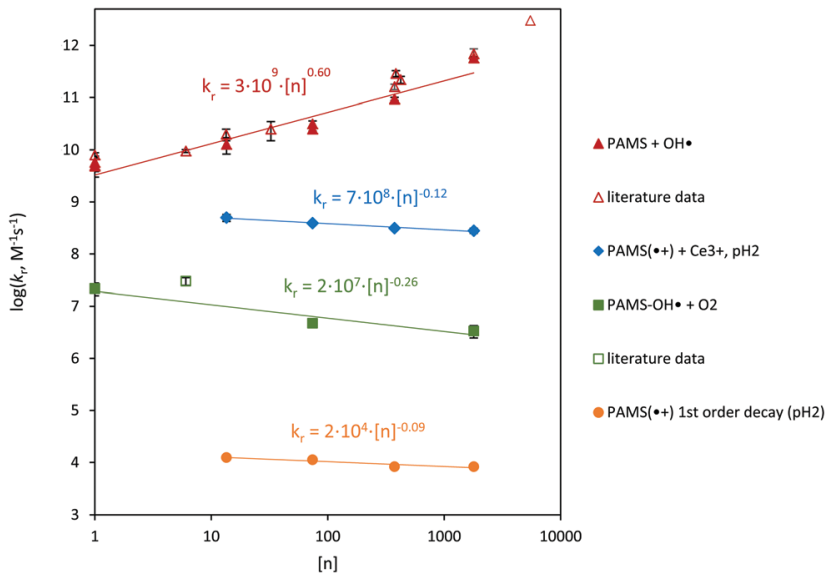

Fig. 6 Combined results for the reactions studied. Rate constants are plotted versus the degree of polymerisation, $[n]$. Literature data refer to Behar (1991), ${ }^{37}$ Behar and Rabani (1988), ${ }^{38}$ Bhardwaj et al. (2001) ${ }^{39}$ and Dockheer et al. (2010) ${ }^{26}$ for PSS and PAMSS, as well as control experiments. 'Reaction exponents': $\theta=0.60 \pm 0.08$ for PAMSS $+\mathrm{OH}^{\bullet}, \theta=$ $-0.12 \pm 0.01$ for PAMSS $^{\bullet+}+\mathrm{Ce}^{3+}, \theta=-0.26 \pm 0.07$ for PAMSS $\left(-\mathrm{OH}^{\bullet}\right)+\mathrm{O}_{2}$ and $\theta=-0.09 \pm 0.02$ for the first order decay of PAMSS ${ }^{*}$.

intramolecular $\pi-\pi$ interaction. As a result, the interaction can lower the rate of $\mathrm{H}_{2} \mathrm{O}$ addition. Taking the molar concentration of $\mathrm{H}_{2} \mathrm{O}$ for a dilute solution, $k_{-9}$ would be $2( \pm 1) \times 10^{6} \mathrm{M}^{-1} \mathrm{~s}^{-1}$.

\section{Reaction of radical cations with $\mathrm{Ce}^{3+}$}

Excluding the 4-tert-butylbenzenesulfonate $(n=1)$, the radical cations produced from the oligomers/polymers were exposed to $\mathrm{Ce}^{3+}$. For all molecular weights, a decrease in the lifetime of the radical cation was observed with increasing $\mathrm{Ce}^{3+}$ concentration. The influence of $\mathrm{Ce}^{3+}$ was attributed to the reduction of the radical cation back to the starting compound (reaction 11, Fig. 1). Minor bleaching was observed in some cases (Fig. S11A, ESI $\dagger$ ), potentially due to reaction -1 ( $c f$. Fig. 1). From the plot of pseudo-first order reaction rates versus concentration, reaction rate constants were obtained, e.g. for the PAMSS-14600 radical cation in Fig. 5 we obtained $k_{11}=3.9( \pm 0.2) \times 10^{8} \mathrm{M}^{-1} \mathrm{~s}^{-1}$ (see ESI $\dagger$ for other $M_{\mathrm{w}}$ ).

As a validation exercise, experiments were conducted for a lower PAMSS (73 800) and higher persulfate concentrations, as well as under higher $\mathrm{pH}$ (Fig. S12, ESI $\dagger$ ). The same value for $k_{11}$ was obtained for the series when fitting the kinetic traces over a short time regime, indicating the stability of the method. Nevertheless, the observed rate constants are higher at $\mathrm{pH} \sim 3$, as compared to $\mathrm{pH} \sim 2$. An offset of $2.9( \pm 0.2) \times 10^{4} \mathrm{~s}^{-1}$ between regressions for $\mathrm{pH} \sim 3$ and $\mathrm{pH} \sim 2$ was obtained. The offset is partially attributed to the acid-base equilibrium (reaction, 9/-9, Fig. 1) (see previous section).

The influence of molecular weight on the reaction between the PAMSS radical cation and $\mathrm{Ce}^{3+}$ was considered. The 'reaction exponent' is $-0.12 \pm 0.01$, i.e. $k_{11} \sim[n]^{-0.12 \pm 0.01}$. The value is similar to that observed for the reaction between the radical cation and $\mathrm{H}_{2} \mathrm{O}$ (previous section), -0.09 (Fig. 6). The negative values support the interpretation that the thermochemistry of the radical cation is affected intramolecularly. Intramolecular charge-radical stabilization has already been confirmed on a fundamental level: chemical reactivity is controlled by radicals flanking the charged groups or by charged groups flanking the radicals. ${ }^{36}$ For the radical cations, too, a significant stabilization is implied, which may be expressed as $\theta<0$, eqn (10). The radical cation is initially produced on the outer 'surface' of the polymer coil with a high degree of polymerization (diffusion limited). Quantumchemical stabilization ( $g$, eqn (10)) can be a $\pi$-donation into the outer-surface cation hole (i.e. the electron deficiency), effectively delocalizing (transferring) the cation hole to center of the polymer. It is conceivable that the polymer dynamics ( $z$, eqn (10)) are also affected, for example, through bridging between polymer segments to facilitate radical stabilization.

Extrapolation of the data resulted in $k_{11}=6.4( \pm 0.7) \times$ $10^{8} \mathrm{M}^{-1} \mathrm{~s}^{-1}$ for the reaction between 4-tert-butyl-benzenesulfonate radical cation and $\mathrm{Ce}^{3+}$ (Fig. 6). No literature data could be found for reactions of $\mathrm{Ce}^{3+}$ with aromatic radical cations. However, the ferrous ion $\left(\mathrm{Fe}^{2+}\right)$ reacts with (reduces) the radical cation of anisole with a rate constant of $k=6 \times 10^{8} \mathrm{M}^{-1} \mathrm{~s}^{-1}$ (pH 1.0) and with pseudocumene and isodurene radical cations with $k=6( \pm 1) 10^{7} \mathrm{M}^{-1} \mathrm{~s}^{-1}(\mathrm{pH} 2.5-3.5) .{ }^{16}$ These reactions are dependent on the ionic strength of the solution and, potentially, the polarity of the cation (Nolte et al., in prep.). ${ }^{32}$

\section{Conclusion}

The reaction between PAMSSS and $\mathrm{OH}^{\bullet}$ borders the diffusionlimit, resulting in the formation of hydroxycyclohexadienyl, i.e. $\mathrm{OH}$ radical adducts, $\operatorname{Ar}\left(-\mathrm{OH}^{\bullet}\right)$. These adducts can react with $\mathrm{O}_{2}, k_{\mathrm{r}}=3 \times 10^{6-7} \mathrm{M}^{-1} \mathrm{~s}^{-1}$, depending on the molecular weight, to produce $\mathrm{O}_{2}$ adducts. Even though $\operatorname{Ar}\left(-\mathrm{OH}^{\bullet}\right)$ reacts with $\mathrm{O}_{2}$, the effectiveness of this reaction depends on the thermodynamic equilibrium of $\mathrm{H}_{2} \mathrm{O}$ elimination/addition, which is a function of $\mathrm{pH}$. Under acidic conditions, the $\mathrm{OH}$-adduct eliminates $\mathrm{H}_{2} \mathrm{O}$ to form a radical cation. The polymeric radical cation was shown to react with $\mathrm{Ce}^{3+}$ with rate constants of 3-5 $\times 10^{8} \mathrm{M}^{-1} \mathrm{~s}^{-1}$ influenced by intramolecular stabilization, likely including radical-charge $(\pi-\pi)$ interaction. Radical cations could not be observed for the monomeric compound (4-tert-butyl-benzenesulfonate), for which no intramolecular stabilization is possible, potentially also due to the fast backward reaction $\left(\mathrm{H}_{2} \mathrm{O}\right.$ addition). The competition between the reaction pathways involving $\mathrm{Ce}^{3+}$ (the repair reaction) or $\mathrm{O}_{2}$ (as an indicator for irreversible damage) can be fine-tuned by modifying the size and structure of PAMSSS through its effect on both steric/clustering and redox properties, with the 'repair' reaction with $\mathrm{Ce}^{3+}$ generally being more efficient (compared to $\mathrm{O}_{2}$ ) for shorter polymer chains.

The results of this study show that repair and stabilization of polymeric radicals can be achieved using cerium ions and neighboring groups via suitable thermochemical and kinetic interactions. This has ramifications for the design of durable arylene type fuel cell membranes and polymeric materials in general. The results also provide a basis for more fundamentally understanding the mechanisms behind conventional 
antioxidants in medicine, such as ceria nanoparticles, and represent a starting point for improvement of additives that detoxify radicals or intermediates formed therefrom, e.g., via damage transfer or repair pathways.

\section{Conflicts of interest}

The authors have no conflicts of interest to disclose.

\section{Acknowledgements}

Funding by the Swiss National Science Foundation (SNSF) is gratefully acknowledged (grant no. 175493). Personal discussions with A. J. Hendriks (RU) aided the interpretation of our results, and were greatly appreciated.

\section{References}

1 L. Gubler, et al., Prospects for Durable Hydrocarbon-Based Fuel Cell Membranes, J. Electrochem. Soc., 2018, 165(6), F3100-F3103.

2 M. Danilczuk, F. D. Coms and S. Schlick, Visualizing Chemical Reactions and Crossover Processes in a Fuel Cell Inserted in the ESR Resonator: Detection by Spin Trapping of Oxygen Radicals, Nafion-Derived Fragments, and Hydrogen and Deuterium Atoms, J. Phys. Chem. B, 2009, 113, 8031-8042.

3 G. V. Buxton, et al., Critical Review of rate constants for reactions of hydrated electrons, hydrogen atoms and hydroxyl radicals $\left({ }^{\bullet} \mathrm{OH} /{ }^{\bullet} \mathrm{O}^{-}\right)$in Aqueous Solution, J. Phys. Chem. Ref. Data, 1988, 17, 513-886.

4 T. M. Nolte and A. M. J. Ragas, A review of quantitative structure-property relationships for the fate of ionizable organic chemicals in water matrices and identification of knowledge gaps, Environ. Sci.: Processes Impacts, 2017, 19(3), 221-246.

5 L. Gubler and W. H. Koppenol, Hydrocarbon Proton Exchange Membranes, in The Chemistry of Membranes Used in Fuel Cells: Degradation and Stabilization, ed. S. Schlick, John Wiley \& Sons, 2018, pp. 107-138.

6 L. Gubler, T. Nolte and T. Nauser, Antioxidant Strategies for Hydrocarbon-Based Membranes, ECS Trans., 2018, 86(13), 369-379.

7 L. Rubio, et al., Antioxidant and anti-genotoxic properties of cerium oxide nanoparticles in a pulmonary-like cell system, Arch. Toxicol., 2016, 90(2), 269-278.

8 F. D. Coms, H. Liu and J. E. Owejan, Mitigation of Perfluorosulfonic Acid Membrane Chemical Degradation Using Cerium and Manganese Ions, ECS Trans., 2008, 16(2), 1735-1747.

9 L. M. Kohan, J. Meesungnoen, S. Sanguanmith, R. Meesat and J. Jay-Gerin, Radiolysis of the ceric-cerous sulfate dosimeter at elevated temperatures: Monte Carlo simulations, Recent Res. Dev. Phys. Chem., 2014, 11, 15-27, (ISBN: 978-817895-608-4).
10 E. Collinson, F. S. Dainton and J. Kroh, The radiation chemistry of aqueous solutions II. Radical and molecular yields for tritium B-particles, Proc. R. Soc. London, Ser. A, 1962, 265, 422.

11 A. Karakoti, et al., Redox-active radical scavenging nanomaterials, Chem. Soc. Rev., 2010, 39(11), 4422-4432.

12 L. Gubler, S. M. Dockheer and W. H. Koppenol, Radical $\left(\mathrm{HO}^{\bullet}, \mathrm{H}^{\bullet}\right.$ and $\left.\mathrm{HOO}^{\bullet}\right)$ Formation and Ionomer Degradation in Polymer Electrolyte Fuel Cells, J. Electrochem. Soc., 2011, 158(7), B755-B769.

13 B. C. Nelson, et al., Antioxidant Cerium Oxide Nanoparticles in Biology and Medicine, Antioxidants, 2016, 5(2), 15.

14 B. H. J. Bielski, et al., Reactivity of $\mathrm{HO}_{2}{ }^{\bullet} / \mathrm{O}_{2}{ }^{--}$radicals in aqueous-solution, J. Phys. Chem. Ref. Data, 1985, 14(4), 1041-1100.

15 P. Oneill, S. Steenken and D. Schultefrohlinde, Formation of Radical Cations of Methoxylated Benzenes by Reaction with Oh Radicals, $\mathrm{Tl}^{2+}, \mathrm{Ag}^{2+}$, and $\mathrm{So}^{4-}$ in Aqueous-Solution - an Optical and Conductometric Pulse-Radiolysis and Insitu Radiolysis Electron-Spin Resonance Study, J. Phys. Chem., 1975, 79(25), 2773-2779.

$16 \mathrm{~J}$. Holcman, Formation and reactions of radical cations of substituted benzenes in aqueous media. A pulse radiolysis study, Roskilde, Denmark: Risø National Laboratory. Risø-M, No. 1947, 1977.

17 S. Steenken and P. Neta, Transient phenoxyl radicals: Formation and properties in aqueous solutions, in The Chemistry of Phenols, ed. Z. Rappoport, John Wiley \& Sons, 2003, p. 1115.

18 L. Gubler, Radiation Grafted Membranes for Polymer Electrolyte Fuel Cells, Departement Chemie und Angewandte Biowissenschaften, Eidgenössische Technische Hochschule, Zürich, 2016, DOI: 20.500.11850/190017.

19 M. Jonsson, et al., Redox Chemistry of Substituted Benzenes the One-Electron Reduction Potentials of Methoxy-Substituted Benzene Radical Cations, J. Phys. Chem., 1993, 97(43), 11278-11282.

20 S. M. Dockheer, L. Gubler and W. H. Koppenol, Reactions of the tetraoxidosulfate $\left({ }^{\bullet-}\right)$ and hydroxyl radicals with poly(sodium alpha-methylstyrene sulfonate), Phys. Chem. Chem. Phys., 2013, 15(14), 4975-4983.

21 T. Nauser, et al., Reversible Intramolecular Hydrogen Transfer between Cysteine Thiyl Radicals and Glycine and Alanine in Model Peptides: Absolute Rate Constants Derived from Pulse Radiolysis and Laser Flash Photolysis, J. Phys. Chem. B, 2008, 112(47), 15034-15044.

22 R. H. Schuler, L. K. Patterson and E. Janata, Yield for the Scavenging of $\mathrm{OH}^{\bullet}$ Radicals in the Radiolysis of $\mathrm{N}_{2} \mathrm{O}$-Saturated Aqueous-Solutions, J. Phys. Chem., 1980, 84(16), 2088-2089.

23 C. von Sonntag, The Chemical Basis of Radiation Biology, Taylor \& Francis, London, 1987.

24 R. H. Schuler, A. L. Hartzell and B. Behar, Track Effects in Radiation-Chemistry - Concentration-Dependence for the Scavenging of $\mathrm{OH}^{\bullet}$ by Ferrocyanide in $\mathrm{N}_{2} \mathrm{O}$-Saturated Aqueous-Solutions, J. Phys. Chem., 1981, 85(2), 192-199.

25 X. W. Fang, et al., Reversibility in the Reaction of Cyclohexadienyl Radicals with Oxygen in Aqueous-Solution, Chem. - Eur. J., 1995, 1(7), 423-429. 
26 S. M. Dockheer, et al., Damage to fuel cell membranes. Reaction of $\mathrm{HO}^{\bullet}$ with an oligomer of poly(sodium styrene sulfonate) and subsequent reaction with $\mathrm{O}_{2}$, Phys. Chem. Chem. Phys., 2010, 12(37), 11609-11616.

27 B. Oshaughnessy, Effect of Concentration on ReactionKinetics in Polymer-Solutions, Macromolecules, 1994, 27(14), 3875-3884.

28 B. Friedman and B. Oshaughnessy, Kinetics of Intermolecular Reactions in Dilute Polymer-Solutions and Unentangled Melts, Macromolecules, 1993, 26(21), 5726-5739.

29 J. des Cloizeaux, J. Phys., 1980, 41, 223-238.

30 K. Matyjaszewski, Typical features of radical polymerization, in Controlled and living polymerizations: from mechanisms to applications, ed. K. Matyjaszewski and A. H. E. Müller, Wiley-VCH, Weinheim, 2009, ch. 3.2, pp. 105-106.

31 G. Klopman, Chemical Reactivity and Concept of Chargeand Frontier-Controlled Reactions, J. Am. Chem. Soc., 1968, 90(2), 223-234.

32 T. M. Nolte, T. Nauser, L. Gubler and W. J. G. M. Peijnenburg, Thermochemical unification of molecular descriptors to predict radical hydrogen abstraction with low computational cost, Phys. Chem. Chem. Phys., 2019, submitted.
33 T. M. Nolte and W. J. G. M. Peijnenburg, Aqueous-phase photooxygenation of enes, amines, sulfides and polycyclic aromatics by singlet $(\mathrm{a} 1 \Delta \mathrm{g})$ oxygen: prediction of rate constants using orbital energies, substituent factors and quantitative structure-property relationships, Environ. Chem., 2018, 14(7), 442-450.

34 J. J. P. Stewart, MOPAC, Stewart Computational Chemistry, Colorado Springs, CO, USA, 2016.

35 D. Minakata, et al., Development of Linear Free Energy Relationships for Aqueous Phase Radical-Involved Chemical Reactions, Environ. Sci. Technol., 2014, 48(23), 13925-13932.

36 T. Mazur and B. A. Grzybowski, Theoretical basis for the stabilization of charges by radicals on electrified polymers, Chem. Sci., 2017, 8(3), 2025-2032.

37 D. Behar and B. Behar, Pulse-Radiolysis Studies of Aminobenzenesulfonates - Formation of Cation Radicals, J. Phys. Chem., 1991, 95(19), 7552-7556.

38 D. Behar and J. Rabani, Pulse-Radiolysis of Poly(Styrenesulfonate) in Aqueous-Solutions, J. Phys. Chem., 1988, 92(18), 5288-5292.

39 Y. K. Bhardwaj, et al., Radiation effect on poly(p-sodium styrene sulphonate) of different degrees of polymerization in aqueous solution: pulse radiolysis and steady state study, Radiat. Phys. Chem., 2001, 62(2-3), 229-242. 